\title{
Pengujian Reliabilitas Instrumen Terhadap Variabel Kontinu Untuk Pengukuran Konsentrasi Klorofil-a Perairan
}

\author{
Dwi Haryo Ismunarti ${ }^{1,2 *}$, Muhammad Zainuri ${ }^{2}$, Denny Nugroho Sugianto ${ }^{2}$, Suradi Widjaya Saputra ${ }^{3}$ \\ ${ }^{I}$ Program Doktor Manajemen Sumberdaya Pantai Fakultas Perikanan dan IlmuKelautan, Universitas Diponegoro \\ ${ }^{2}$ Departemen Oseanografi, Fakultas Perikanan dan Ilmu Kelautan, Universitas Diponegoro \\ ${ }^{3}$ Depatemen Manajemen Sumberdaya Perairan, Fakultas Perikanan dan Ilmu Kelautan,Universitas Diponegoro \\ Jl. Prof. H. Soedarto S.H, Tembalang, Semarang, Jawa Tengah 50275 Indonesia \\ Email : dwiharyois@gmail.com
}

\begin{abstract}
Abstrak
Instrumen penelitian adalah alat ukur yang digunakan secara sistematis untuk mengumpulkan data penelitian. Hasil penelitian yang baik diperoleh jika instrumen yang digunakan valid dan reliabel. Reliabilitas instrumen menunjukkan ketepatan atau sejauh mana hasil pengukuran instrumen dapat direplikasi. Reliabilitas menjadi salah satu parameter penting dalam menentukan kualitas suatu instrumen. Penelitian ini bertujuan untuk memilih statistik uji yang paling tepat terhadap pengujian reliabilitas terhadap instrumen untuk konsentrasi klorofil-a perairan. Data konsentrasi klorofil-a perairan diperoleh dari dua instrumen yaitu : metode spektrofotometri dari 14 stasiun pengamatan di Teluk Semarang Jawa Tengah dan penginderaan jauh. Statistik uji yang paling tepat digunakan adalah Intraclass Correlation Coefficients (ICC). Nilai ICC adalah rasio antara varians objek terhadap varians total. Hasil penelitian diperoleh nilai ICC $=0,83$ artinya $83 \%$ keragaman data disebabkan keragaman objek dalam hal ini stasiun penelitian. Tidak terdapat bias pengukuran konsentrasi klorofil-a dari kedua instrumen, karena reliabilitas kedua instrumen mendekati sempurna.
\end{abstract}

Kata kunci : instrumen penelitian, reliabilitas, ICC

\section{Abstract \\ Instrument Reliability Against Continuous Variables for Measurement of Water Chlorophyll-a Concentration}

A research instrument is a measuring tool used systematically to collect the data. A good result of the research is obtained if the instrument is reliable. The reliability of the instrument showed accuracy on instrument measurement could be replicated. Reliability is one of the important parameters in determining the quality of the device. This study is aimed at selecting the most appropriate test of statistics in the reliability of the instrument for chlorophyll-a water concentrations. The data of chlorophyll-a waters concentration is gained from two instruments called spectrophotometric method from 14 observation stations in Semarang Bay, Central Java, and remote sensing. The best test statistic is the Intraclass Correlation Coefficients (ICC). The value on ICC is the ratio between the variance of the object at total variance. The results showed that ICC $=0.83$, meaning that $83 \%$ of a variety of data is due to the diversity of objects in these research stations. There is no bias in measuring the chlorofil-a concentration using the two instruments because the reliability of the two devices is closely perfect.

Keywords: research instruments, reliability, ICC

\section{PENDAHULUAN}

Instrumen penelitian adalah alat ukur yang digunakan secara sistematis untuk mengumpulkan data penelitian (Sugiyono, 2015). Data merupakan nilai karakteristik objek yang diperoleh melalui proses pengukuran atau pengamatan. Pengukuran menghasilkan sekumpulan nilai atau atribut dari objek penelitian, yang disebut variabel penelitian.
Sekumpulan nilai variabel penelitian disebut data, dengan skala ukur kualitatif atau kategorik (nominal dan ordinal) dan skala ukur kuantitaif atau kontinu (interval dan rasio) (Bernhart et. al., 2007; Murti, 2011; Streiner et al., 2015; Lydersen, 2016).

Pengukuran yang benar terhadap variabel penelitian merupakan elemen kunci dari setiap
*Corresponding author

DOI:10.14710/buloma.v9i1.23924 http://ejournal.undip.ac.id/index.php/buloma

Diterima/Received : 27-06-2019

Disetujui/Accepted : 18-09-2019 
metode penelitian. Kesalahan dalam pengukuran disebut bias pengukuran (measurement error). Bias pengukuran bisa ditimbulkan oleh bias instrumen yang digunakan dan bias dalam pelaksanaan pengukuran. Kesalahan dalam pengukuran akan menghasilkan data yang tidak valid dan mengakibatkan hasilpenelitian tidak valid dan tidak benar. Meskipun penelitian dilakukan dengan ukuran sampel besar, keberadaan bias pengukuran mengakibatkan penelitian tidak akan mengenai sasaran dengan benar. Instrumen yang baik harus mengukur dengan benar sesuai dengan apa yang seharusnya diukur (valid) dan konsisten serta andal (reliabel) (Bernhart et al., 2007; Murti, 2011; Streiner et al., 2015; Lydersen2016).

Instrumen yang valid dan reliabel akan menghasilkan penelitian yang valid dan reliabel. Sedangkan suatu instrumen yang mengandung unsur yang menyesatkan, akan menghasilkan penelitian yang kurang baik. Untuk itu setiap instrumen yang digunakan untuk mengumpulkan data perlu dilakukan pengujian validitas dan reliabilitasnya (Sugiyono, 2016 dan Hadi, 2015).

Data konsentrasi klorofil-a perairan pada umumnya diperoleh dari sampel dan penghitungan menggunakan metode spektrofotometri (Riyono, 2006) dan penginderaan jauh. Penginderaan jauh merupakan ilmu pengetahuan dan teknologi untuk mendapatkan data guna mempelajari karakteristik objek tanpa menyentuh objek tersebut. Teknologi penginderaan jauh menghasilkan perekaman dan penyimpanan data setiap waktu dan terus menerus. Basis data yang dihasilkan merupakan data spasio temporal yang memiliki dimensi banyak dan kompleks (Syah, 2010). Pemanfaatan data penginderaan jauh dalam sistem informasi geografis telah banyak dilakukan pada bidang oseanografi (Hu et al., 2012; Syah et al., 2015 dan Wirasatriya et al., 2017).

\section{MATERI DAN METODE}

Materi pada penelitian ini berupa sampel air laut digunakan untuk pengukuran kandungan konsentrasi klorofil-a perairan. Pengambilan sampel dilakukan di perairan Teluk Semarang pada tanggal 13 dan 14 Mei 2017. Waktu pengambilan dari pagi hingga siang hari (jam 07.00 sampai jam 14.00) pada empat belas titik stasiun pengamatan. Titik stasiun ditentukan berdasarkan nonprobability sampling yaitu sampling sistematis (Sugiyono, 2015). Penetuan titik stasiun dimulai jarak terdekat dari pantai menuju ke laut lepas sejauh 15 mil. Jarak ditentukan sehingga 14 titik tersebar di wilayah perairan Teluk Semarang. Sebaran titik stasiun terdapat pada Gambar 1.

Sumber data konsentrasi klorofil-a berasal dari data primer dan data sekunder. Pengukuran klorofil-a dan penghitungan menggunakan metode spektrofotometri sebagaimana dilakukan Riyono (2006). Analisa klorofil-a dilakukan di Laboratorium Kimia Laut Departemen Ilmu Kelautan FPIK UNDIP. Data penginderaan jauh konsentrasi klorofil-a bersumber dari data citrasatelit Aqua MODIS (Moderate Resolution Imaging Spectroradiometer) yang diunduh dari http: www.oceancolor.gfsc.nasa.gov. Data

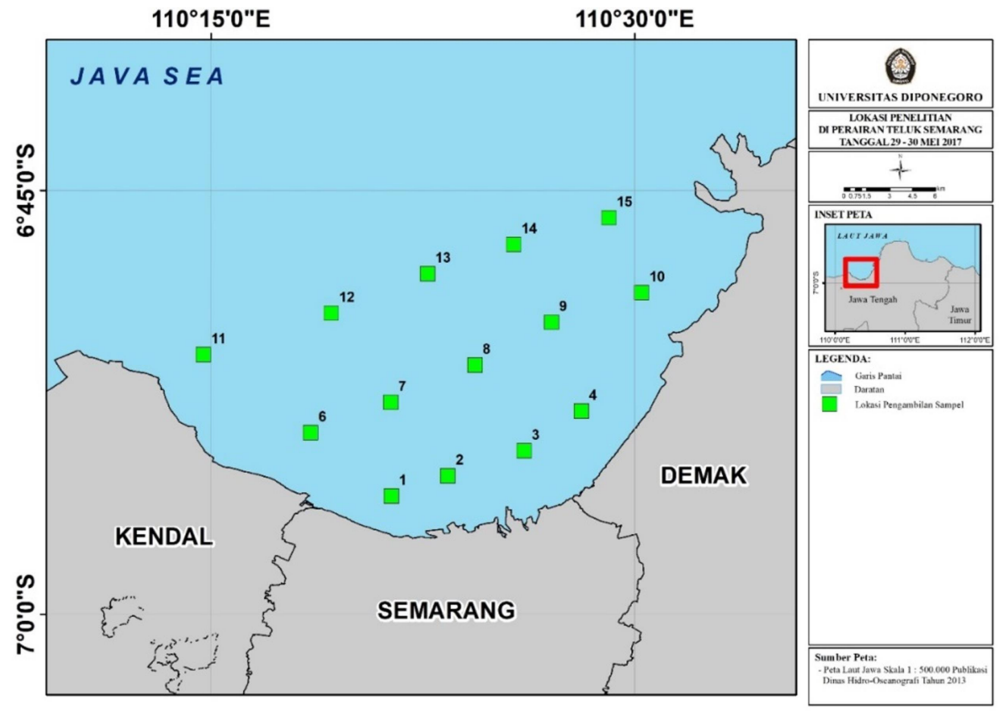

Gambar 1. Peta sebaran titik stasiun penelitian. 
merupakan data harian level 2 dengan resolusispasial $1 \times 1 \mathrm{~km}$. Data yang digunakan merupakan komposit untuk bulan Mei 2017 pada koordinat yang sama dengan stasiun pengambilan sampel. Jika tidak diperoleh data pada waktu yang bersesuaian paling tidak data pada bulan atau musim yang sama.

Terdapat sejumlah statistik uji/alat yang sering digunakan untuk melakukan pengujian terhadap reliabilitas instrumen, yaitu: korelasi person, Cohen"s kappa, Intraclass Correlation Coefficient /ICC, Root mean square error (RMSE) dan Maen absolute error (MAE).

Korelasi Pearson megukur tingkat hubungan secara linear dua variabel berbeda dan berskala kontinu. Korelasi Pearson terkadang juga digunakan untuk menguji reliabilitas terhadap dua instrumen. Nilai Korelasi Pearson berkisar antara negatif satu sampai satu, dalam hal ini hanya berlaku kisaran nilai nol sampai satu. Korelasi Pearson dihitung berdasarkan persamaan :

$$
r=\sqrt{\frac{\sum\left(x_{1 i}-\bar{x}_{1}\right)\left(x_{2 i}-\bar{x}_{2}\right)}{\sqrt{\left(x_{1 i}-\bar{x}_{1}\right)^{2}} \sqrt{\left(x_{2 i}-\bar{x}_{2}\right)^{2}}}}
$$

Intraclass Correlation Coefficient /ICC adalah statistik uji reliabilitas terhadap satu variabel yang sama dengan skala kontinu yang dilakukan pengukuran dengan dua atau lebih alat pengukur yang berbeda. Jika pengukuran dilakukan pada dua alat pengukuran dengan variabel berskala diskret, maka statistik uji yang digunakan coefficient agreement Cohen's kappa (kesepakatan Kappa). ( Murti, 2011; Gwet, 2014; Lydersen 2016; Zaki, 2017; Mehta et. al.,2018).

Nilai ICC adalah rasio varians objek terhadap varians total. Nilai ICC berkisar dari nol sampai satu $(0 \leq \mathrm{ICC} \leq 1)$. ICC mendekati nilai satu menunjukkan reliabilitas instrumen mendekati sempurna, varian data lebih disebabkan karena varian antar objek bukan karena antar instrumen. Nilai ICC mendekati nol atau rendah dapat terjadi karena ketidak konsistensi instrumen, ketidakstabilan objek yang diukur dan karena

Tabel 1. Kriteria statistik ICC

\begin{tabular}{cc}
\hline ICC & Kriteria \\
\hline ICC $<0,4$ & Poor \\
$0,4 \leq$ ICC $<0,75$ & Fair to good \\
ICC $\geq 0,75$ & Excellent \\
\hline
\end{tabular}

Sumber :Zaki, 2017 situasi pengukuran yang tidak mendukung (Barnhart et al., 2007; Lydersen, 2016; Zaki, 2017; Mehta et al., 2018). Tabel 1 membagi kriteria tingkatan reliabilitas berdasarkan nilai ICC.

Varians total berasal dari tiga sumber yaitu objek penelitian, instrumen dan random error.

$$
y_{i j}=\mu+\alpha_{i}+\beta_{j}+\varepsilon_{i j}
$$

Keterangan : $y_{i j}=$ data dari objek ke i dan instrumen ke $\mathrm{j} ; \quad \mu=$ konstanta sebagai faktor koreksi; $\alpha_{i}$ pengaruh objek ke I; $\beta_{j}=$ pengaruh instrumen ke $\mathrm{j}$ dan $\varepsilon_{i j}=$ sisaan atau randomerror.

Jika variasi antar instrumen diasumsikan random, maka rumus ICC:

$$
I C C=\frac{\sigma_{\text {objek }}^{2}}{\sigma_{\text {objek }}^{2}+\sigma_{\text {instrumen }}^{2}+\sigma_{\text {error }}^{2}}
$$

Jika variasi instrumen diasumsikan tetap atau diabaikan, maka rumus ICC:

$$
I C C=\frac{\sigma_{\text {objek }}^{2}}{\sigma_{\text {objek }}^{2}+\sigma_{\text {error }}^{2}}
$$

Keterangan $: \sigma_{\text {Objek }}^{2}=$ ukuran varian objek penelitian; $\sigma_{\text {instrumen }}^{2}=$ varian instrumen; $\sigma_{\text {error }}^{2}$ $=$ varian karena faktor random.

Pendugaan varian dihitung menggunakan pendekatan analisis ragam dengan dua faktor ( ANOVA two way). Instrumen sebagai faktor pertama dan objek sebagai faktor kedua, sedangkan interaksi merupakan komponen dari galat.

Root mean square error (RMSE) dan Maen absolute error (MAE) umumnya digunakan dalam klimatologi, peramalan, dan analisis regresi. RMSE dan MAE digunakan untuk mengukur perbedaan antara dua variabel kontinu yang mengekspresikan fenomena yang sama, misalkan perbandingan antara prediksi dan pengamatan, satu teknik pengukuran terhadap teknik pengukuran alternatif. RMSE dan MAE menggambarkan seberapa tersebarnya selisih nilai peramalan dan pegukuran. Nilai RMSE dan MAE dari nol sampai tak hingga.RMSE dihitung berdasarkan persamaan :

$$
R M S E=\sqrt{\frac{\sum\left(x_{1 i}-x_{2 i}\right)^{2}}{n}}
$$


MAE adalah rata-rata absolut perbedaan antara kedua variabel, perbedaan ada ketika rata-rata nilai kedua variabel berbeda (Willmott and Matsuura, 2005). MAE dihitung dengan persamaan :

$$
M A E=\frac{\sum\left|x_{1 i}-x_{2 i}\right|}{n}
$$

\section{HASIL DAN PEMBAHASAN}

Perbandingan koefisien korelasi, ICC, RMSE dan $M A E$

Perbandingan statistik uji koefisien korelasi, ICC, RMSE dan MAE dilakukan pada empat kondisi berbeda sebagaimana terdapat pada Gambar 2. Sebaran titik tepat dilalui oleh

Tabel 2. Two way ANOVA

\begin{tabular}{|c|c|c|c|c|}
\hline $\begin{array}{c}\text { Sumber } \\
\text { varian }\end{array}$ & Sum of Square(SS) & $\begin{array}{l}\text { Degree of } \\
\text { fredom }(\mathrm{df})\end{array}$ & Mean Square & Pendugaan varians ${ }^{2}$ \\
\hline $\begin{array}{l}\text { Instrumen } \\
\text { (kolom) }\end{array}$ & $\sum \frac{x_{\cdot j}^{2}}{b}-\frac{x_{. \cdot}^{2}}{k b}$ & $\mathrm{k}-1$ & $\frac{S S_{\text {instrumen }}}{k-1}$ & $\frac{M S_{\text {instrumen }}-M S_{\text {error }}}{b}$ \\
\hline $\begin{array}{l}\text { Objek } \\
\text { penelitian }\end{array}$ & $\sum \frac{x_{i .}^{2}}{k}-\frac{x_{. .}^{2}}{k b}$ & b-1 & $\frac{S S_{\text {objek }}}{b-1}$ & $\frac{M S_{\text {objek }}-M S_{\text {error }}}{k}$ \\
\hline Error & $\begin{array}{l}\text { SS total - } \\
\text { SSinstrumen - } \\
\text { SS objek }\end{array}$ & $(k-1)(b-1)$ & $\frac{S S \text { error }}{(k-1)(b-1)}$ & MS error \\
\hline
\end{tabular}

Keterangan : k jumlah instrumen, $b$ jumlah objek
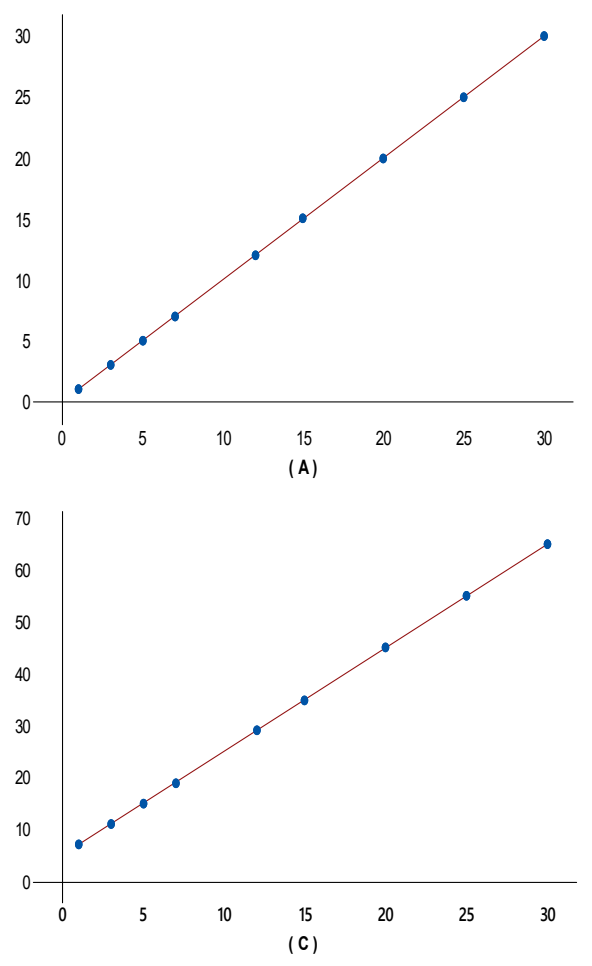
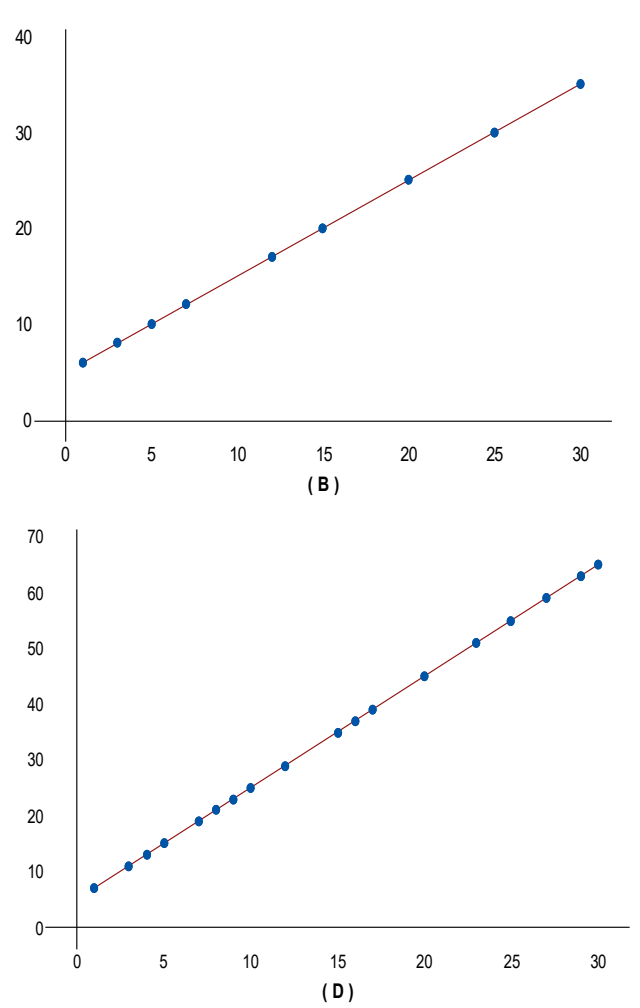

Gambar 2. Persamaan garis (a) $\mathrm{Y}=\mathrm{X}$; (b) $\mathrm{Y}=\mathrm{a}+\mathrm{X}$; (c) $\mathrm{Y}=\mathrm{a}+\mathrm{b} \mathrm{X}$ dan(d) $\mathrm{Y}=\mathrm{a}+\mathrm{b} \mathrm{X}$ dengan jumlah data $n$ lebih banyak 
Tabel 3. Nilai koefisien korelasi $r$, ICC MAE dan RMSE

\begin{tabular}{ccccc}
\hline & $\mathrm{a}$ & $\mathrm{b}$ & $\mathrm{C}$ & $\mathrm{D}$ \\
\hline persamaan & $\mathrm{Y}=\mathrm{X}$ & $\mathrm{Y}=\mathrm{a}+\mathrm{X}$ & $\mathrm{Y}=\mathrm{a}+\mathrm{bx}$ & $\mathrm{Y}=\mathrm{a}+\mathrm{bx}$ \\
Korelasi $\mathrm{r}$ & 1 & 1 & 1 & 1 \\
ICC & 1 & 1 & 0,94 & 0,8 \\
MAE & 0 & 5 & 3 & 19,5 \\
RMSE & 0 & 5 & 3,7 & 21,5 \\
\hline
\end{tabular}

persamaan garis. Gambar 2 (a) garis tepat memotong titik pusat $(0,0)$ dengan koefisien kemiringan garis 1 , persamaan garis $\mathrm{Y}=\mathrm{X}$. Gambar 2 (b) garis memotong sumbu Y di $(0, a)$ dengan koefisien kemiringan garis 1 , persamaan garis $\mathrm{Y}=\mathrm{a}+\mathrm{X}$. Gambar 2 (c) garis memotong sumbu Y di $(0, a)$ dan multiplikatif terhadap $X$ dengan koefisian kemiringan garis $b$, dengan persamaan garis $\mathrm{Y}=\mathrm{a}+\mathrm{bX}$. Sedangkan Gambar 2 (d) persamaan garis $\mathrm{Y}=\mathrm{a}+\mathrm{bX}$ dengan jumlah data $\mathrm{n}$ lebih besar. Sebaran titik tepat dilalui oleh persamaan garis.

Perbandingan statistik uji validitas dan reliabilitas sebagaimana ditunjukkan pada Tabel 3. Koefisien korelasi pearson (r) diperoleh nilai satu pada empat kondisi, hal ini menunjukkan adanya hubungan yang kuat antara variabel $\mathrm{X}$ dan Y. Penambahan konstanta dan multiplikatif terhadap X tidak merubah nilai korelasi (r) selama hubungan kedua variabel linear. Koefisien korelasi merupakan ukuran kekuatan hubungan secara linier antara variabel $\mathrm{X}$ dan $\mathrm{Y}$. Hubungan yang kuat dengan koefisien $\mathrm{r}=1$ tidak berarti kekonsistenan kedua instrumen yang kuat (Zaki, 2017).

ICC pada kondisi (a) dan (b) bernilai satu. ICC adalah rasio varians yang disebabkan objek terhadap varians total. Penambahan oleh konstanta a pada persamaan (b) telah dikoreksi oleh nilai konstanta $\mu$ pada persamaan (2) sehingga nilai ICC = 1 (Barnhart et al., 2007; Lydersen, 2016; Zaki, 2017; Mehta et al., 2018). Multiplikatif terhadap nilai X pada Y untuk persamaan (c) dan (d) meyebabkan penurunan nilai ICC.

Penghitungan MAE dan RMSE pada data (a) $\mathrm{MAE}=\mathrm{RMSE}=0$ karena kedua nilai pengukuran $\mathrm{X}$ dan $\mathrm{Y}$ sama, selisih nilai $\mathrm{X}$ dan $\mathrm{Y}$ nol. Nilai menjadi lebih besar untuk data (b) karena ada selisih nilai $\mathrm{X}$ dan $\mathrm{Y}$ sebesar nilai konstanta a pada persamaan. Sedangkan MAE dan RMSE persamaan (d) lebih besar dari persamaan (c) disebabkan jumlah data yang lebih besar. Penambahan jumlah data sebesar $\mathrm{n}$ meningkatkan nilai MAE dan RMSE kurang lebih sebesar $\sqrt{n}$ (Willmott and Matsuura, 2005).

Dari keempat statistik uji tersebut koefisien ICC lebih tepat digunakan untuk menguji reliabilitas antar instrumen dibanding koefisien korelasi r, MAE dan RMSE.

\section{Uji terhadap reliabilitas citra satelit dan spkektofotometri}

Hasil penghitungan konsentrasi klorofil-a dari sampel air yang diperoleh dari empat belas stasiun pengamatan dan konsentrasi klorofil-a dari citra pada bulan Mei 2017 pada titik koordinat yang sama diperoleh pada Tabel 3. Rata-rata klorofil a berdasarkan citra lebih tinggi dibanding hasil pengukuran lapangan yaitu $3,59 \mathrm{mg} /$ liter dan 2,38 $\mathrm{mg} /$ liter, sebagaimana terdapat pada Gambar 3.

Konsentrasi klorofil-a dari instrumen citra merupakan refleksi dari beberapa band spektral yang dominan (Rrs). Konsentrasi klorofil diperoleh berdasarkan perhitungan mengikuti persamaan ( Hu et al., 2012), yaitu :

$$
\begin{aligned}
C l=R_{r s}(555) & -\left[R_{r s}(443)+\frac{555-443}{670-443}\right. \\
& \left.*\left(R_{r s}(670)-R_{r s}(443)\right)\right] \\
& \cong R_{r s}(555)-0,5\left(R_{r s}(443)\right. \\
& \left.+R_{r s}(670)\right)
\end{aligned}
$$

Sedangkan konsentrasi klorofil-a hasil pengukuran lapangan dihitung menggunakan metode spektrofotometri. Konsentrasi klorofil diperoleh berdasarkan penghitungan panjang gelombang (E) yang digunakan yang terabsorbansi, jika $V e$ volume ekstrak, $V_{S}$ volume sampel dan d diameter kuvet maka konsentrasi klorofil-a dihitung menggunakan persamaan (Riyono, 2006).

$$
C l=\frac{\left\{11,85\left(E_{664}\right)-1,54\left(E_{647}\right)-0,08\left(E_{630}\right)\right\} \times V_{e}}{V_{s} \times d}
$$


Perbedaan nilai konsentrasi disebabkan perbedaan pendekatan yang digunakan. Untuk itu perlu dilakukan uji terhadap reliabilitas hasil perhitungan kedua instrumen. Instrumen dikatakan valid jika instrumen tersebut mengukur variabel yang seharusnya diukur dan persamaan diturunkan berdasarkan konstruksi teoritis yang dihasilkan berdasarkan definisi teori yang menjadi dasar penyusunan instrumen tersebut. Instrumen dikatakan reliabel jika hasil pengukuran stabil atau konsisten. Varian data yang muncul disebabkan karena varian dari objek (Hadi, 2016),

Tabel 3. Data klorofil a hasil pengukuran lapangan dan citra

\begin{tabular}{|c|c|c|c|c|c|}
\hline \multirow{2}{*}{ Stasiun } & Pengukuran lapangan & Citra & \multirow{2}{*}{$x_{i}=x_{i 1}+x_{i 2}$} & \multirow{2}{*}{$\left(x_{i 1}+x_{i 2}\right)^{2}$} & \multirow{2}{*}{$x_{i 1}^{2}+x_{i 2}^{2}$} \\
\hline & $x_{i 1}$ & $x_{i 2}$ & & & \\
\hline 1 & 4,66 & 7,81 & 12,47 & 155,57 & 82,73 \\
\hline 2 & 6,06 & 7,69 & 13,75 & 188,99 & 95,82 \\
\hline 3 & 3,97 & 5,39 & 9,36 & 87,70 & 44,86 \\
\hline 4 & 2,44 & 3,46 & 5,90 & 34,80 & 17,91 \\
\hline 5 & 3,31 & 5,59 & 8,90 & 79,18 & 42,19 \\
\hline 6 & 0,87 & 4,41 & 5,28 & 27,87 & 20,17 \\
\hline 7 & 1,09 & 2,71 & 3,80 & 14,46 & 8,54 \\
\hline 8 & 1,77 & 2,58 & 4,35 & 18,91 & 9,79 \\
\hline 9 & 2,28 & 2,86 & 5,14 & 26,39 & 13,37 \\
\hline 10 & 2,17 & 2,41 & 4,57 & 20,91 & 10,49 \\
\hline 11 & 0,73 & 1,08 & 1,81 & 3,29 & 1,71 \\
\hline 12 & 0,80 & 0,91 & 1,70 & 2,90 & 1,46 \\
\hline 13 & 0,41 & 1,30 & 1,71 & 2,94 & 1,86 \\
\hline 14 & 2,76 & 2,05 & 4,81 & 23,10 & 11,80 \\
\hline \multirow{2}{*}{$x_{\cdot j}=\sum_{\substack{i=1 \\
x_{i j}^{2}}}^{14} x_{i j}$} & 33,33 & 50,23 & $x_{. .}=83,56$ & 687,02 & 362,69 \\
\hline & 1110,77 & 2523,25 & 3634,02 & & \\
\hline
\end{tabular}

SS total $=362,69-\frac{83,56^{2}}{2 \times 14}=113,32$

SS instrumen $=\frac{3634,02}{14}-\frac{83,56^{2}}{2 \times 14}=10,21$

SS objek $=\frac{687,02}{2}-\frac{83,56^{2}}{2 \times 14}=94,14$

SS error $=113,32-10,21-94,14=8,98$

Tabel 4. ANOVA two way

\begin{tabular}{ccccc}
\hline Sumber varian & Sum of Square(SS) & Degree of fredom $(\mathrm{df})$ & Mean Square & $\begin{array}{c}\text { Pendugaan varian } \\
\sigma^{2}\end{array}$ \\
\hline SS instrumen & 10,21 & $2-1=1$ & 10,20 & 0,68 \\
SS objek & 94,14 & $14-1=13$ & 7,24 & 3,28 \\
SS error & 8,98 & $27-1-13=13$ & 0,69 & 0,69 \\
Total & 113,32 & $2 \times 14-1=27$ & 4,20 & \\
\hline
\end{tabular}

$\widehat{I C C}=\frac{3,28}{3,28+0,69}=0,83$ 


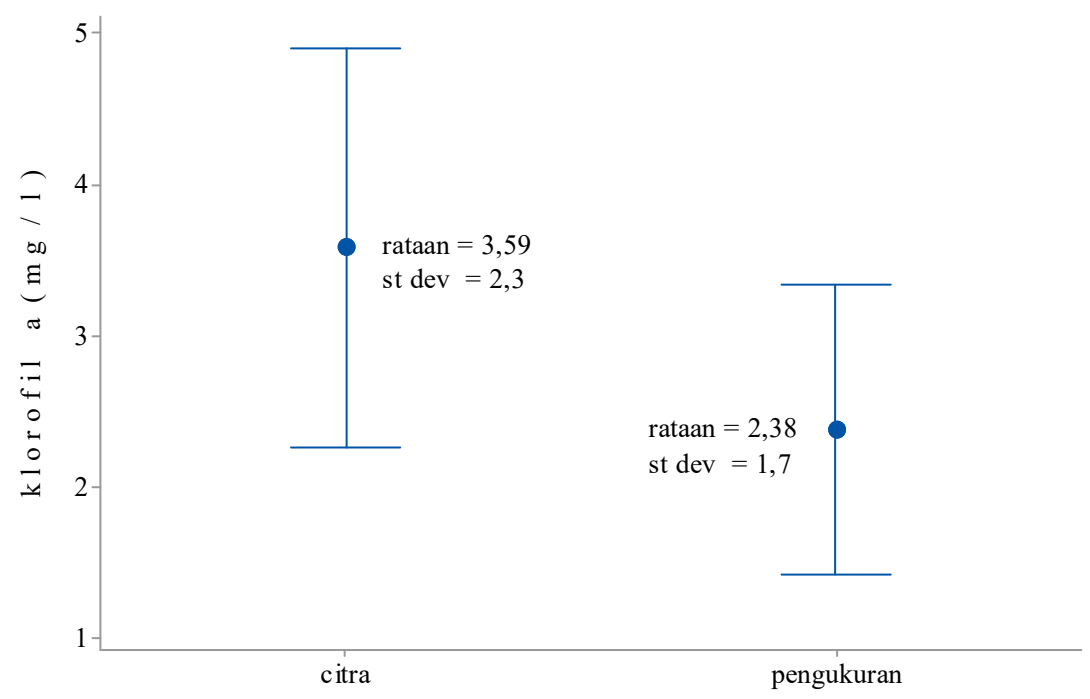

Gambar 3. Selang kepercayaan 95\% rataan klorofil-a

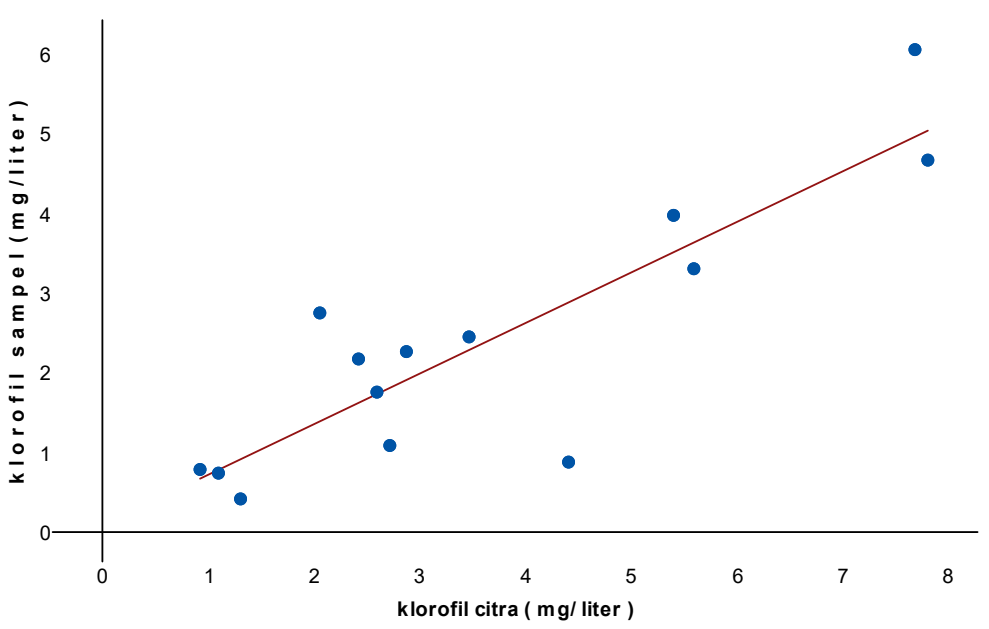

Gambar 4. Klorofil-a (mg/liter) antara citra dan pengukuran lapangan

Nilai ICC diperoleh 0,83 atau mendekati nilai satu artinya reliabilitas dan validitas kedua instrumen mendekati sempurna (Zaki, 2017). Variasi data $83 \%$ berasaldarivariasiobjek dalam hal ini stasiunamatan,17 \% berasaldarivariasi instrumen dan kesalahan yang bersifat acak.Hal ini menunjukkan kedua instrumen yaitu citra dan pengukuran dengan spektofotometri valid dan reliabel untuk menghasilkan data konsentrasi klorofil a.

\section{KESIMPULAN}

Koefisien ICC lebih tepat digunakan untuk menguji reliabilitas dan validitas instrumen dibanding koefisien korelasi, MAE dan RMSE. Koefisien ICC untuk instrumen konsentrasi klorofil a yaitu citra dan pengukuran dengan metode spektrofotometri menghasilkan nilai ICC $=0,83$. Hal ini menunjukkan kedua instrumen $87 \%$ valid dan reliabel untuk mengukur konsentrasi klorofil a.

\section{UCAPAN TERIMAKASIH}

Artikel ini merupakan bagian dari disertasi doktor pada Program Doktor Manajemen Sumberdaya Pantai FPIK UNDIP. Terimakasih disampaikan kepada Ditjen Penguatan Riset dan Pengembangan Kemenristek Dikti yang telah membiayai penelitian melaui Hibah Disertasi Doktor. Terimakasih disampaikan kepada Ditjen Sumberdaya Iptek dan Dikti Kemenristek Dikti yang telah membiayai pendidikan doktor melaui program BPPDN. 


\section{DAFTAR PUSTAKA}

Bernhart, H.X., Haber, M.J. \& Lin, L.I. 2007. An Overview on Assessing Agreement withContinuous Measurement. Journal of Biopharmaceutical Statistics. 17:529-569

Gwet, K.L. 2014. Hand Book of Inter-rater Reliability the Definitive Guide to Measuring the Extent of Agreement among Raters. Fourth Edition Published by Advanced Analytics, LLC; in the United States of America.

Hadi, S. 2016. Metodologi Riset. Penerbit Pustaka Pelajar, Yogyakarta. $651 \mathrm{hlm}$

Hu, C., Lee,Z., \& Franz, B. 2012. Chlorophyll $a$ Algorithms for Oligotrophic Oceans: A Novel Approach Based on Three-band Reflectance Difference. Journal of geophysical research. 117(C1):1-25

Lydersen, S.2016 Measuring Agreement between Raters. $84 \mathrm{p}$ Presentation at RBUP

Med Calc 2007. Inter-rater agreement. Med Calc Version 9.3.7.0-(C) 1993-2007. Frank Schoonjans. Last modified: 15 August 2007. MedCalc Software, Broekstraat 52, 9030 Mariakerke, Belgium

Mehta, S., Bastero-Caballero, R.F., Sun, Y., Zhu,R., Murphy, D.K., Hardas, B. \& Koch,G. 2018.Performance of Intraclass Correlation Coefficient (ICC) as a Reliability Index under Various Distributions in Scale Reliability studies. Statistics in medicine. 37 (18): 2734-2752.

Murti, B. 2011. Validitas dan reliabilitas pengukuran Fakultas Kedokteran, Universitas Sebelas Maret, $19 \mathrm{p}$.
Riyono, H.S. 2006. Beberapa Metode Pengukuran Klorofil Fitoplankton di Laut. Jurnal Oseana, 31(3):33-34

Streiner, D.L., Norman, G.R. \& Cairney, J. 2015. Health Measurement Scales A practical guide to their development and use. fifth edition Oxford university press. $415 \mathrm{p}$

Sugiyono. 2015. Metode Penelitian dan Pengembangan. Penerbit Alfabeta Bandung. $710 \mathrm{hlm}$

Syah, A.F., 2010. Penginderaan jauh dana plikasinya di wilayah pesisir dan lautan. Jurnal Kelautan: Indonesian Journal of Marine Science and Technology, 3(1):18-28.

Syah, A.F., Saitoh,S.I., Alabia, I.D. \& Hirawake, T. 2015. Predicting Potential Fishing Zones for Pacific Saury (Cololabis saira) with Maximum Entropy Models and Remotely Sensed Data. Fishery Bulletin, 114(3):330342.

Willmott, C.J. \& Matsuura, K.. 2005. Advantages of the mean absolute error (MAE) over the root mean square error (RMSE) in assessing average model performance. Climate Research, 30:79-82

Wirasatriya, A., Prasetyawan, I.B., Triyono, C.D., Muslim, \& Maslukah, L.2017. Effect of ENSO on the variability of SST and Chlorophyll-a inJava Sea. IOP Conference Series: Earth and Environmental Science, 116:012063

Zaki, R. 2017. Validation of Instrument Measuring Continuous Variable, Advances in Statistical Methodologies and Their Application to Real Problems. Intech open Science. pp : 217-237. 